\title{
Climate warming caused changes in the bud swelling phenophase of introduced conifer species, considering the aspect of hardiness zones in their natural habitats
}

\author{
Asta Malakauskiené $\dot{1}^{*}$, \\ Adomas Vitas $^{2}$ \\ ${ }^{1}$ Kaunas Botanical Garden, \\ Vytautas Magnus University, Ž. E. Žilibero 6, \\ 46324 Kaunas, Lithuania \\ ${ }^{2}$ Faculty of Natural Sciences, \\ Vytautas Magnus University, Vileikos 8, \\ 44404 Kaunas, Lithuania
}

Background. Changing climatic conditions cause changes in tree phenology, which is important for the survival of species and their spread in local ecosystems. This study concentrated on long-term (1957-2016 or 1980-2016) observations of 11 conifer species introduced to Lithuania with the aim to evaluate the response of their bud swelling phenophase to climate warming, considering the hardiness zones of their natural habitats.

Materials and Methods. Sequences of the start date of the bud swelling phenophase of 11 introduced conifer species (Abies veitchii, Larix decidua, L. kaempferi, L. laricina, L. $\times$ marschlinsii, L. sibirica, L. sukaczewii, Picea mariana, Pinus mugo, Taxus baccata and Thuja occidentalis) were analysed. Data were collected from the paper archives of Kaunas Botanical Garden of Vytautas Magnus University (VMU). Sequences of bud swelling start dates were transformed into sequences of number of days from the beginning of the year.

Results. Results indicated an advance of the bud swelling phenophase of ten conifer species introduced to Lithuania (the speed of changes varied from -0.10 to -0.98 days/year in the 1980-2016 period) and a delay of Larix sukaczewii (respectively, +0.12 days/ year) of the bud swelling phenophase, mainly influenced by the March temperature.

Conclusions. The connection between the observed conifer species hardiness zone of the natural habitat and the reaction of the bud swelling phenophase to climate warming could be observed only when species from one genus were compared. To confirm this phenomenon, a research on a larger amount of introduced species with wider habitat hardiness zone options is needed in future.

Keywords: bud swelling phenophase, climate warming, conifer species, hardiness zone

\footnotetext{
* Corresponding author: E-mail: a.malakauskiene@bs.vdu.lt
} 


\section{INTRODUCTION}

Due to changing climatic conditions many plant species across the globe have shifted their ranges or changed behaviours such as advanced bud burst, leaf unfolding, flowering, a delay in leaf colouring and fall, and consequently an extended duration of the vegetation period (Jensen, 2003; Juknys et al., 2012). The timing of phenophases in trees is known to affect their biological functions and ecological interactions at several organizational scales (Delpierre et al., 2016).

Temperature is usually considered a major driver of most phenological events (Chuine, Cour, 1999; Kramer et al., 2000; Chmielewski et al., 2012; Menzel et al., 2006b). Three potential environmental drivers (chilling, photoperiod, and temperature) of spring phenology interact in complexand species-specific ways that are yet to be clearly disentangled (Basler, Korner, 2014). In time and space scales, spring phenology is more sensitive to climate changes than autumn (Kalvāne et al., 2009; Menzel et al., 2006a; Juknys et al., 2016). The analysis of longterm time series for different deciduous tree species has shown that in Lithuania leaf unfolding is the most sensitive to temperatures in March and April and illustrates that forcing temperature is the main driver of the advancement of leaf unfolding (Juknys et al., 2016). The response of spring phenology to precipitation is markedly weaker (Gordo, Sanz, 2010; Polgar, Primack, 2011). The beginning of bud burst and flowering phenophases has become significantly advanced (Baroniene, Romanovskaja, 2004).

The ability to adjust to a changed environment is not constant throughout the year but depends on the state of plant development (Kramer et al., 2000). Climatic warming will decrease the risk of freezing damage to several tree species even though bud burst will be hastened (Kramer, 1994). The changing climate may contribute to better adaptation of introduced species, especially in boreal climate zones.

The aim of this study was to evaluate the response of the bud swelling phenophase of $11 \mathrm{co}$ nifer tree species introduced to Lithuania (Abies veitchii, Larix decidua, Larix kaempferi, Larix la- ricina, Larix $\times$ marschlinsii, Larix sibirica, Larix sukaczewii, Picea mariana, Pinus mugo, Taxus baccata and Thuja occidentalis) to climate warming, considering the hardiness zones of their natural habitats by means of long-term phenological observation data from Kaunas Botanical Garden of Vytautas Magnus University.

\section{MATERIALS AND METHODS}

Long-term phenological observations (for some species data from paper archives were available starting from 1956) of species introduced to Lithuania were carried out by the dendrologists of Kaunas Botanical Garden of Vytautas Magnus University (Central Lithuania). The possible error of investigation in VMU Botanical Garden was \pm 5 days. Sequences of the start date of the bud swelling phenophase of 11 introduced conifer species (Abies veitchii Lindl., Larix decidua Mill., Larix kaempferi (Lamb.) Carr., Larix laricina (Du Roi) K. Koch, Larix $\times$ marschlinsii Mill., Larix sibirica Ledeb., Larix sukaczewii Dylis, Picea mariana (Mill.) Britton, Sterns \& Poggenb., Pinus mugo Turra, Taxus baccata L. and Thuja occidentalis L.) were analysed. The longest data sequences (1957-2016) were available for Larix decidua, L. kaempferi, L. laricina, L. sibirica, Pinus mugo, and Taxus baccata. Data sequences from 1980 were available for all 11 observed conifer species. Sequences of bud swelling start dates were transformed into sequences of the number of days from the beginning of the year.

The mean annual temperature in Lithuania rose by $0.7-0.9^{\circ} \mathrm{C}$, summer droughts became more frequent $(1992,1994,2002,2006)$, and the trend of increasing precipitation during cold seasons and decreasing in warm seasons was observed in the early 21 st century (Galvonaitè et al., 2007; Rimkus et al., 2007). Analysis of the variation of long-term climatic parameters revealed that the rise of the mean temperature in central Lithuania by $0.93^{\circ} \mathrm{C}$ from 1920 to 2013 was statistically significant $(p<0.01)$, while the significant change of the precipitation amount was not estimated (Juknys et al., 2016). The mean annual temperature $\left({ }^{\circ} \mathrm{C}\right)$ and precipitation amount $(\mathrm{mm})$ data 
from 1956 to 2015 are presented in Fig. 1 and Fig. 2, respectively. The data for these figures were received from Kaunas Meteorological Station, which is situated at the distance of $3.6 \mathrm{~km}$ from VMU Kaunas Botanical Garden.

The change of the mean air temperature from 1957 to 2016 was $+1.83^{\circ} \mathrm{C}(p<0.05)$ (approximated by the linear trend method), and the change of the precipitation amount +7.20 $(\mathrm{mm})(p>0.05)$. These results prove that climate was warming in the environment of the observed 11 conifer species.
A statistical analysis of the results was performed using Statistica 10 software. Descriptive parameters (mean, standard error) were calculated for statistical data analysis. Changes from 1957 (or 1980) to 2016 were approximated by the linear trend method, using the starting values (the start date) and the end values (the end date). Pearson correlation coefficients were calculated to evaluate the impact of monthly temperatures and precipitation amount on the start date of bud swelling. To evaluate data similarities, a cluster analysis was carried out (by joining

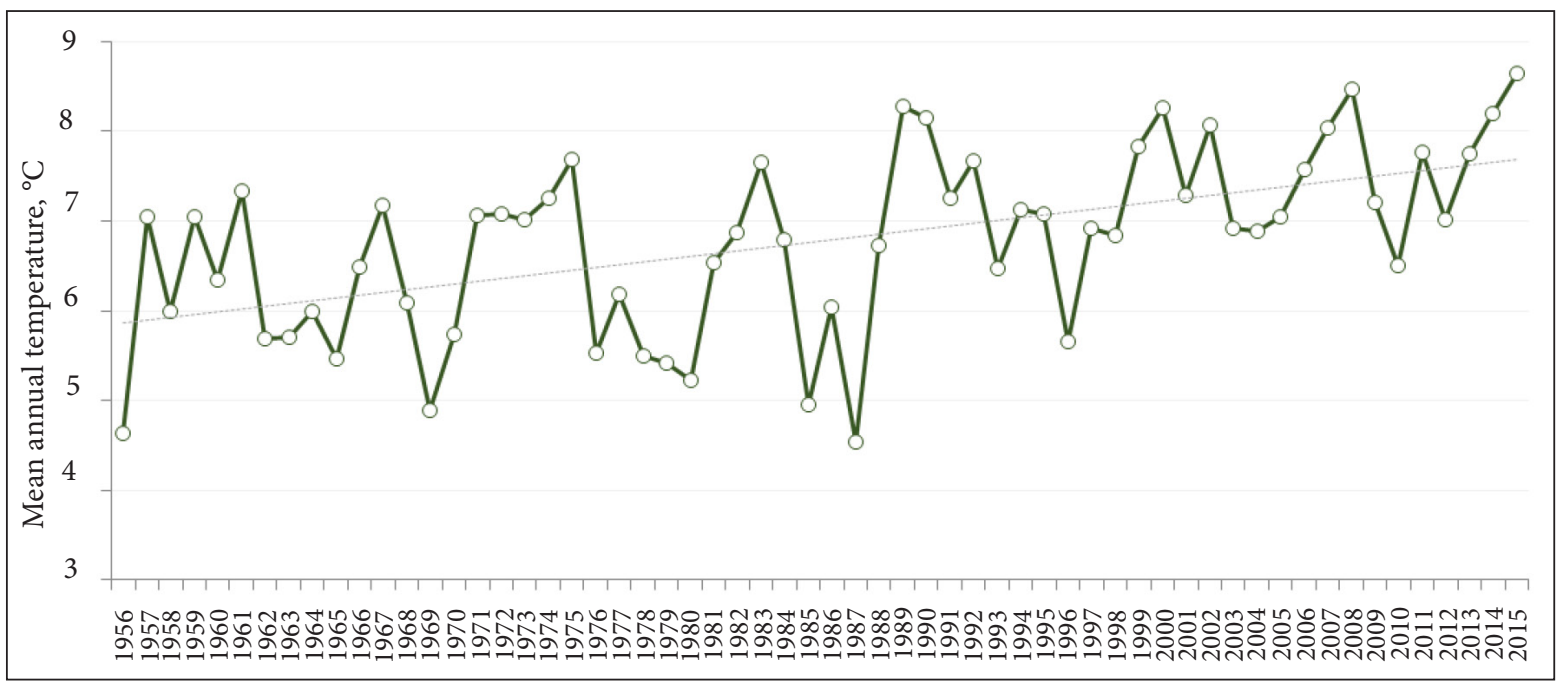

Fig. 1. The dynamics of the mean annual daily temperature $\left({ }^{\circ} \mathrm{C}\right)$ in $1956-2015$ in Central Lithuania

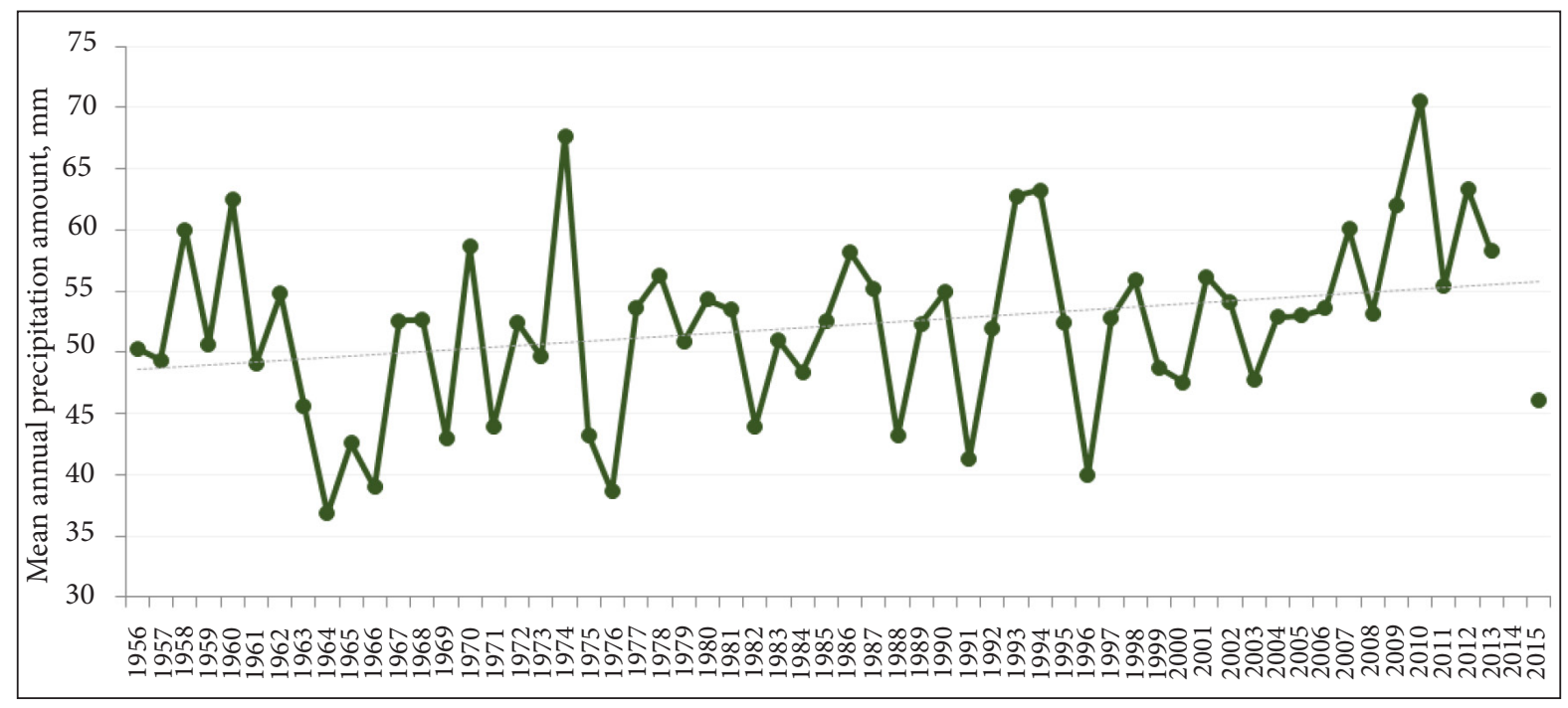

Fig. 2. The dynamics of the mean annual precipitation amount (mm) from 1956 to 2015 in Central Lithuania 
tree clustering method, using single linkage as amalgamation (joining) rule, and Euclidean distances as distance metric).

\section{RESULTS}

The dynamics of available data on the start date (data transformed into the number of days from the beginning of the year) of the bud swelling phenophase of six conifer species from 1957 to 2016 is presented in Fig. 3, and the dynamics of the same parameter of other five conifer species from 1980 to 2016 is given in Fig. 4.

The start of the bud swelling phenophase advanced on average from 10 (L. kaempferi) to 35 days (T. baccata) in the period of 1957 to 2016,

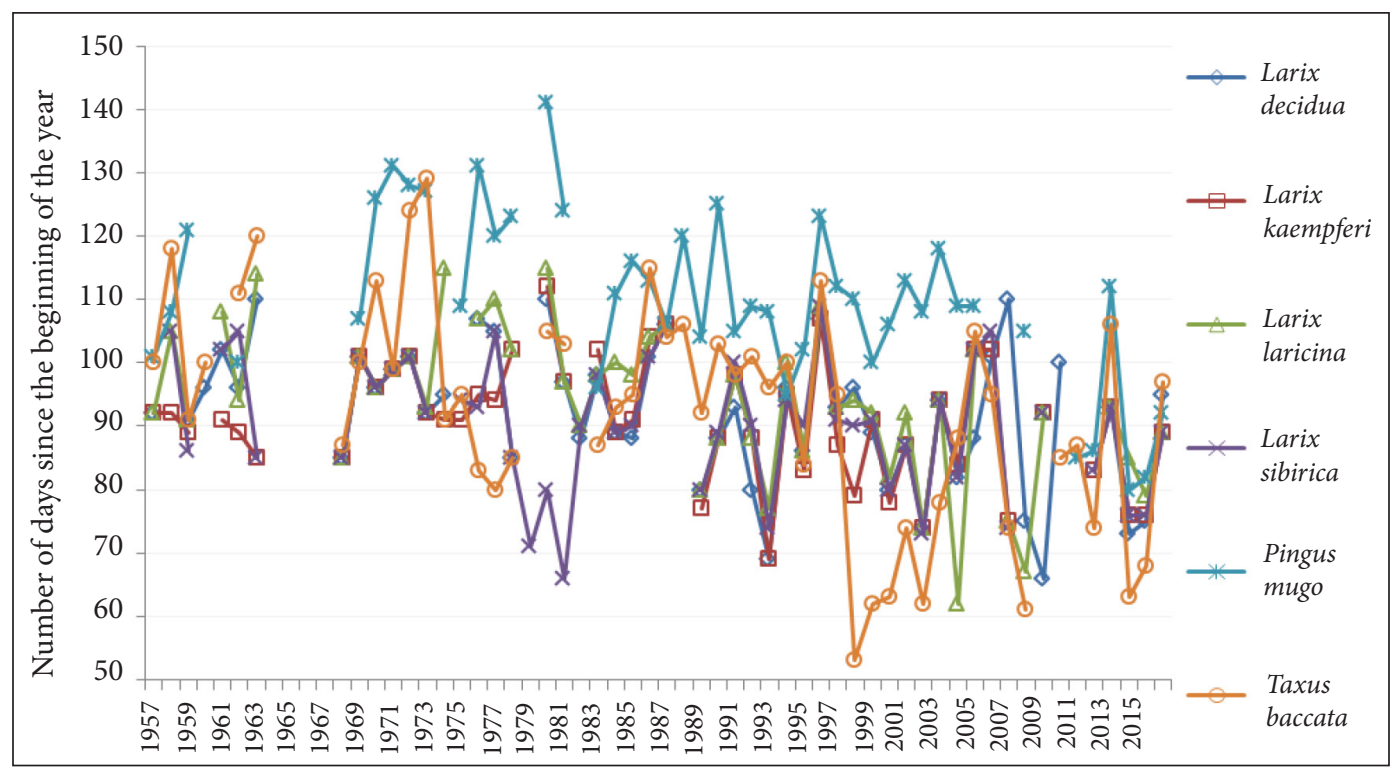

Fig. 3. The dynamics of the start date of the bud swelling phenophase of Larix decidua, L. kaempferi, L. laricina, L. sibirica, Pinus mugo and Taxus baccata, 1957-2016

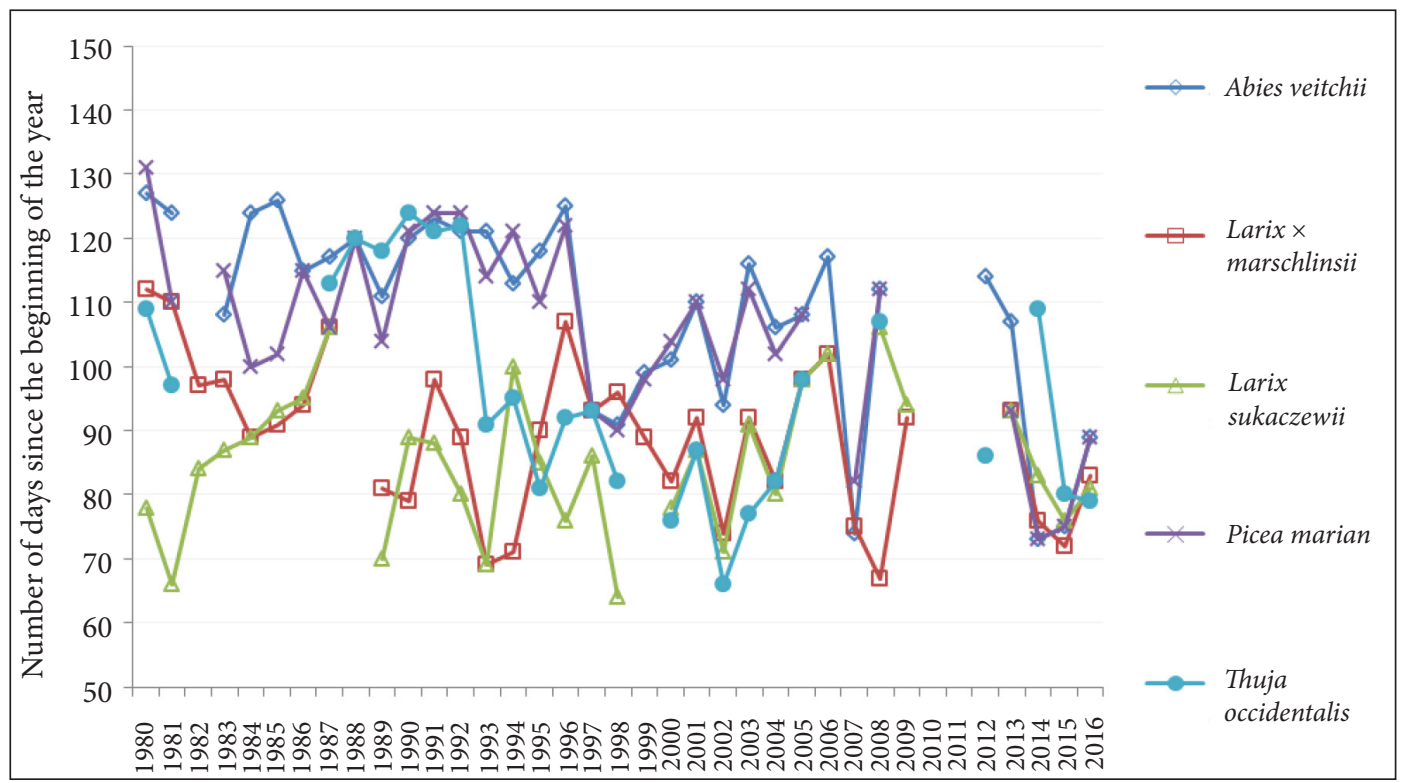

Fig. 4. The dynamics of the start date of the bud swelling phenophase of Abies veitchii, Larix $\times$ marschlinsii, L. sukaczewii, Picea mariana and Thuja occidentalis, 1980-2016 
while the speed of changes was from -0.17 to -0.59 days/year, respectively (Table 1 ). In comparison to the longer period (1957-2016), the results of the shorter period (1980-2016) show that changes in the bud swelling phenophase were faster: the speed of changes for the same species in the shorter period was -0.52 days/year (L. kaempferi) and -0.75 days/year (T. baccata) (Table 2). The most rapid changes in the 19802016 period were estimated for Abies veitchii and

Table 1. Changes of the start date of the conifer bud swelling phenophase, 1957-2016

\begin{tabular}{c|c|c|c|c}
\hline Species & $\begin{array}{c}\text { Hardiness } \\
\text { zone of natu- } \\
\text { ral habitat }\end{array}$ & $\begin{array}{c}\text { Transformed mean bud } \\
\text { swelling start date } \pm \text { stand- } \\
\text { ard error, 1957-2016 (days) }\end{array}$ & $\begin{array}{c}\text { Change, } \\
\text { 1957-2016 } \\
\text { (days) }\end{array}$ & $\begin{array}{c}\text { The speed of change, } \\
\text { 1957-2016 (days/year) }\end{array}$ \\
\hline Larix decidua & $3-6$ & $92.00 \pm 1.53$ & -15.31 & -0.26 \\
\hline Larix kaempferi & $5-7$ & $90.88 \pm 1.35$ & -10.06 & -0.17 \\
\hline Larix laricina & $2-6$ & $94.00 \pm 1.71$ & -22.01 & -0.37 \\
\hline Larix sibirica & $1-5$ & $90.39 \pm 1.48$ & -11.03 & -0.18 \\
\hline Pinus mugo & $3-7$ & $110.16 \pm 2.02$ & -28.13 & -0.47 \\
\hline Taxus baccata & $6-8$ & $92.52 \pm 2.41$ & -35.30 & -0.59 \\
\hline
\end{tabular}

Table 2. Changes in the start date of the conifer bud swelling phenophase, 1980-2016

\begin{tabular}{c|c|c|c|c}
\hline Species & $\begin{array}{c}\text { Hardiness } \\
\text { zone of natu- } \\
\text { ral areal }\end{array}$ & $\begin{array}{c}\text { Transformed mean bud } \\
\text { swelling start date } \pm \text { standard } \\
\text { error, 1980-2016 (days) }\end{array}$ & $\begin{array}{c}\text { Change, } \\
\text { 1980-2016 } \\
\text { (days) }\end{array}$ & $\begin{array}{c}\text { The speed of } \\
\text { change, 1980- } \\
\text { 2016 (days/year) }\end{array}$ \\
\hline Abies veitchii & $3-6$ & $108.85 \pm 2.66$ & -35.13 & -0.98 \\
\hline Larix decidua & $3-6$ & $89.62 \pm 1.97$ & -11.48 & -0.32 \\
\hline Larix kaempferi & $5-7$ & $89.63 \pm 1.94$ & -15.20 & -0.42 \\
\hline Larix laricina & $2-6$ & $90.59 \pm 2.10$ & -19.70 & -0.55 \\
\hline Larix $\times$ marschlinsii & $5-7$ & $89.06 \pm 2.08$ & -18.79 & -0.52 \\
\hline Larix sibirica & $1-5$ & $88.61 \pm 1.81$ & -3.74 & -0.10 \\
\hline Larix sukaczewii & $1-5$ & $85.32 \pm 2.01$ & +4.35 & +0.12 \\
\hline Picea mariana & $2-6$ & $105.74 \pm 2.59$ & -33.26 & -0.92 \\
\hline Pinus mugo & $3-7$ & $107.03 \pm 2.34$ & -28.03 & -0.78 \\
\hline Thuja occidentalis & $2-7$ & $96.20 \pm 3.40$ & -31.18 & -0.87 \\
\hline Taxus baccata & $6-8$ & $88.14 \pm 2.86$ & -26.91 & -0.75 \\
\hline
\end{tabular}

Picea mariana (the speed of changes was -0.98 and -0.92 days/year, respectively) and the slowest for Larix sibirica and L. sukaczewii (-0.10 and +0.12 days/year, respectively).

The advance of the start date of the bud swelling phenophase of the introduced conifer species was most influenced by the March temperature in Lithuania: data of nine species correlated statistically significantly with this temperature (correlation coefficient $r$ ranged from -0.40 for Picea mariana to -0.71 for Larix kaempferi) (Table 3). The temperature of February was also important for some species: six species out of 11 observed correlated significantly, but the strength of correlation was less (ranged from -0.37 for Larix sibirica and Taxus baccata to -0.58 for L. laricina).

The connection between the hardiness zone of natural habitat of the observed conifer species and the reaction of the bud swelling phenophase to climate warming was not clearly expressed if all species from different genera 
Table 3. Correlation coefficients $\mathbf{r}$ between the start date of the conifer bud swelling phenophase and climatic parameters (late winter-early spring temperatures and precipitation amount)

\begin{tabular}{|c|c|c|c|c|c|c|c|c|}
\hline Species & $\begin{array}{c}\text { January } \\
\text { temp. }\end{array}$ & $\begin{array}{c}\text { February } \\
\text { temp. }\end{array}$ & $\begin{array}{c}\text { March } \\
\text { temp. }\end{array}$ & $\begin{array}{l}\text { April } \\
\text { temp. }\end{array}$ & $\begin{array}{l}\text { January } \\
\text { precip. }\end{array}$ & $\begin{array}{c}\text { February } \\
\text { precip. }\end{array}$ & $\begin{array}{l}\text { March } \\
\text { precip. }\end{array}$ & $\begin{array}{l}\text { April } \\
\text { precip. }\end{array}$ \\
\hline Abies veitchii & -0.26 & -0.32 & -0.54 & -0.34 & -0.39 & -0.19 & -0.31 & 0.00 \\
\hline Larix decidua & -0.32 & -0.54 & -0.49 & -0.44 & -0.17 & -0.28 & -0.45 & 0.21 \\
\hline Larix laricina & -0.33 & -0.58 & -0.68 & -0.35 & -0.24 & -0.37 & -0.38 & 0.23 \\
\hline Larix sibirica & -0.32 & -0.37 & -0.54 & -0.16 & -0.22 & -0.23 & -0.30 & 0.18 \\
\hline Larix sukaczewii & -0.31 & -0.34 & -0.31 & -0.11 & 0.03 & -0.22 & -0.09 & -0.18 \\
\hline Picea mariana & 0.00 & -0.23 & -0.40 & -0.19 & -0.18 & -0.15 & -0.11 & 0.11 \\
\hline Pinus mugo & -0.23 & -0.06 & -0.47 & -0.45 & -0.38 & -0.13 & -0.35 & -0.25 \\
\hline Thuja occidentalis & 0.03 & 0.07 & -0.06 & -0.29 & -0.33 & -0.29 & 0.03 & -0.06 \\
\hline Larix kaempferi & -0.42 & -0.56 & -0.71 & -0.42 & -0.21 & -0.39 & -0.32 & 0.10 \\
\hline Larix $\times$ marschlinsii & -0.47 & -0.45 & -0.68 & -0.52 & -0.45 & -0.22 & -0.43 & -0.16 \\
\hline Taxus baccata & -0.27 & -0.37 & -0.56 & -0.61 & -0.25 & -0.44 & -0.33 & 0.08 \\
\hline
\end{tabular}

Note: values presented in bold type were statistically significant at $p<0.05$.

were compared. The cluster analysis showed two major clusters: the first included all Larix species, Taxus baccata and Thuja occidentalis (their habitats belong to hardiness zones ranging from 1 to 8 ), and the second included Abies veitchii, Picea mariana and Pinus mugo (hardiness zones 2 to 7) (Fig. 5). When species from one genus were compared (six different species of Larix), the connection with the hardiness zone was ex- pressed more clearly: the reaction of bud swelling of the species introduced from colder (1-5) hardiness zones was slower (the speed of changes in the bud swelling phenophase was -0.10 days/year for Larix sibirica and +0.12 days/year for L. sukaczewii) to climate warming than of the species introduced from warmer (5-7) hardiness zones ( -0.42 days/year for Larix kaempferi and -0.52 days/year for L. $\times$ marschlinsii).

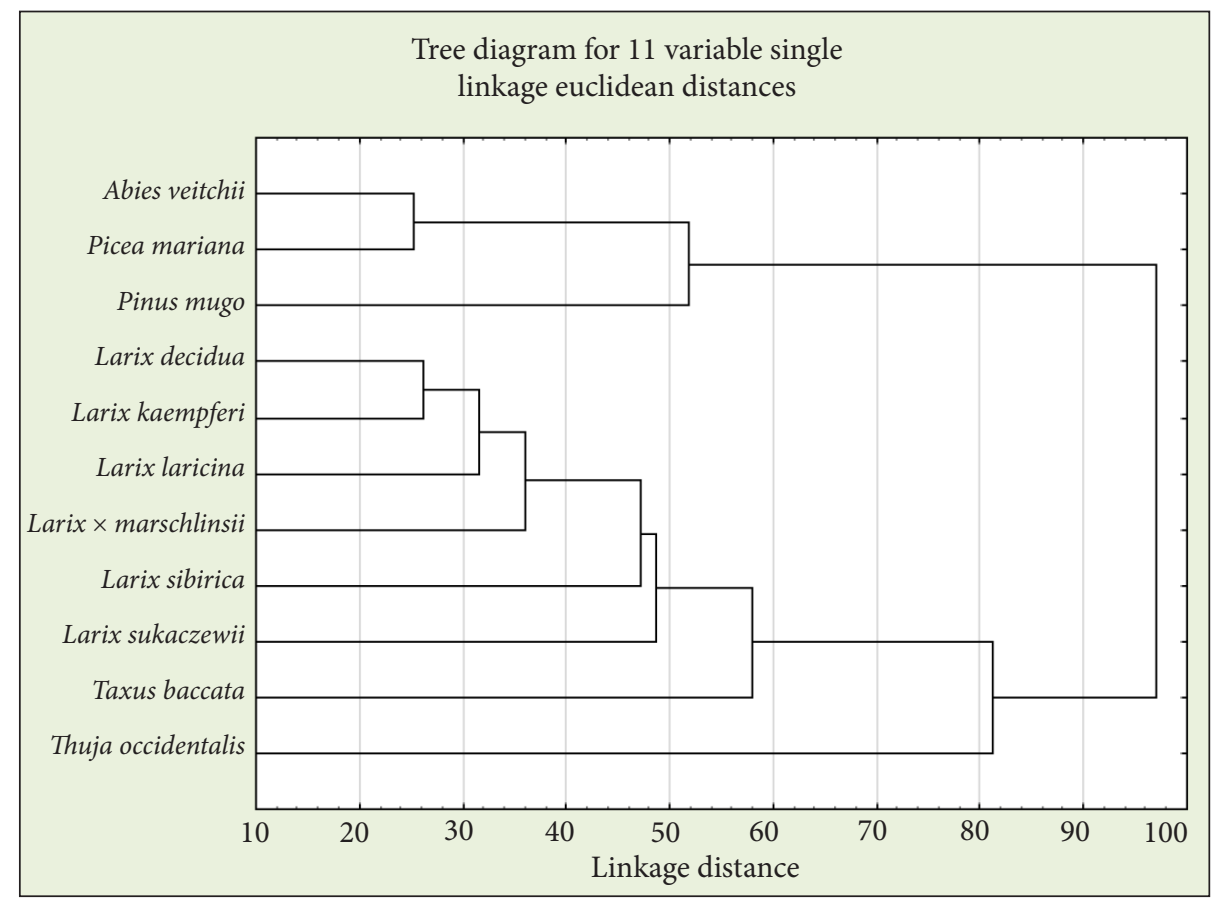

Fig. 5. Similarities in bud swelling phenophase data of $11 \mathrm{co}-$ nifer species (19802016) calculated by joining tree clustering analysis 


\section{DISCUSSION}

Many studies on the changes in tree phenology have been dealing with native or local species (Kramer et al., 2010; Morin et al., 2010; Nordli et al., 2008; Primack et al., 2009). In this study we analysed changes in early spring phenology of introduced conifer species. The data of obtained results indicate an advance of the bud swelling phenophase of ten conifer species introduced to Lithuania (the speed of changes varied from -0.10 to -0.98 days/ year in the 1980-2016 period) and a delay of the bud swelling phenophase of Larix sukaczewii (respectively, +0.12 days/year). They were mainly influenced by the March temperature and also depended on the hardiness zone of the species natural habitat within the range of one genus.

Summarizing results on the phenology of herbs, shrubs, and trees, Parmesan and Yohe (2003) concluded that there was a mean shift towards earlier spring timing of 2.3 days per decade in $79 \%$ of woody plants, $32 \%$ of herbaceous plants, and $72 \%$ of mixed plants. However, based on the changes in spring phenology for temperate-zone species, Root et al. (2003) concluded that the timing of events shifted $5.1 \pm 0.1$ days earlier in a decade. In most cases our findings coincide with these results (changes in the bud swelling phenophase of the introduced conifer species varied in the range of 1 to 9.8 days per decade), except Abies veitchii and Picea mariana distinguished by a faster reaction to climate warming.

Our results did not show the connection between hardiness zone of natural habitat of the observed conifer species and the reaction of the bud swelling phenophase to the climate warming when all species from different genera were compared, but this connection could be seen when species from one genus were compared. A study in Canada revealed that trees change their hardiness zones of natural habitats with changing climate: obvious northward shifts in hardiness zones across western Canada were estimated and 62 northern tree species over 50 -year interval on average shifted 57 kilo- meters northwards (McKenney et al., 2014). A research on a larger amount of introduced species with wider habitat hardiness zone options is needed in future.

\section{CONCLUSIONS}

The start date of the bud swelling phenophase of ten conifer species introduced to Lithuaniaadvanced (the speed of changes varied from -0.10 to -0.98 days/year in the 1980-2016 period), and that of Larix sukaczewii delayed (+0.12 days/year, respectively). The most rapid changes in the 1980-2016 period were estimated for Abies veitchii and Picea mariana (the speed of changes was -0.98 and -0.92 days/ year, respectively) and the slowest for Larix sibirica and L. sukaczewii ( -0.10 and +0.12 days/ year, respectively).

The advance of the bud swelling phenophase start date of the introduced conifer species was most influenced by the March temperature (the correlation coefficient $r$ ranged from -0.40 for Picea mariana to -0.71 for Larix kaempferi). The temperature of February was also important for some species (six species out of $11 \mathrm{ob-}$ served correlated significantly).

The connection between the hardiness zone of natural habitat of the observed conifer species and the reaction of the bud swelling phenophase to climate warming could be observed only if species of one genus were compared (six different species of Larix). The reaction to climate warming of bud swelling of the species introduced from colder (1-5) hardiness zones was slower (the changes in the speed of bud swelling phenophase were -0.10 days/year for Larix sibirica and +0.12 days/year for $L$. sukaczewii) than of the species introduced from warmer (5-7) hardiness zones ( -0.42 days/year for Larix kaempferi and -0.52 days/year for L. $\times$ marschlinsii). To confirm this phenomenon, a research on larger amount of introduced species with wider habitat hardiness zone options is needed in future.

Received 30 April 2016 Accepted 9 June 2017 


\section{References}

1. Baronienė V, Romanovskaja D. Klimato šiltèjimo įtaka augalų sezoniniam vystymuisi Lietuvoje 1961-2003 metais. Vagos. 2005; 66(19): 24-32. Lithuanian.

2. Chmielewski FM, Blümel K, Pálesová I. Climate change and shifts in dormancy release for deciduous fruit crops in Germany. Climate Res. 2012; 54: 209-19.

3. Chuine I, Cour P. Climatic determinants of budburst seasonality in four temperate-zone tree species. New Phytol. 1999; 143: 339-49.

4. Basler D, Korner Ch. Photoperiod and temperature responses of bud swelling and bud burst in four temperate forest tree species. Tree Physiol. 2014; 34(4): 377-88.

5. Delpierre N, Vitasse Y, Chuine I, Guillemot J, Bazot S, Rutishauser T, Rathgeber CBK. Temperate and boreal forest tree phenology: from organ-scale processes to terrestrial ecosystem models. Ann Forest Scie. 2016; 73: 5-20.

6. Galvonaitė A, Misiūnienė M, Valiukas D, Buitkuvienė M. Lietuvos klimatas. Vilnius: Lietuvos hidrometeorologijos tarnyba; 2007. p. 207. Lithuanian.

7. Rimkus E, Kažys J, Junevičiūtė J, Stonevičius E. Lietuvos klimato pokyčių XXI amžiuje prognozè. Geografija. 2007; 43(2): 37-47. Lithuanian.

8. Gordo O, Sanz J. Impact of climate change on plant phenology in Mediterranean ecosystems. Glob Change Biol. 2010; 16: 1082-106.

9. Jensen MN. Consensus on ecological impacts remains elusive. Science. 2003; 301(5634): 38-8.

10. Juknys R, Sujetovienè G, Žeimavičius K, Šveikauskaitė I. Comparison of climate warming induced changes in silver birch (Betula pendula Roth) and lime (Tilia cordata Mill.) phenology. Baltic Forestry. 2012; 18: 25-32.

11. Juknys R, Kanapickas A, Šveikauskaitė I, Sujetovienè G. Response of deciduous trees spring phenology to recent and projected climate change in Central Lithuania. Int. J. Biometeorol. 2016; 60: 1589-602.
12. Kalvāne G, Romanovskaja D, Briede A, Baksiene E. Influence of climate change on phenological phases in Latvia and Lithuania. Climate Res. 2009; 39: 209-19.

13. Kramer K. A modelling analysis of the effects of climatic warming on the probability of spring frost damage to tree species in the Netherlands and Germany. Plant Cell Environ. 1994; 17: 367-77.

14. Kramer K, Degen B, Buschbom J. Modelling exploration of the future of European Beech (Fagus sylvatica L.) under climate change - range, abundance, genetic diversity and adaptive response. Forest Ecol Manag. 2010; 259(11): 2213-22.

15. Kramer K, Leinonen I, Loustau D. The importance of phenology for the evaluation of impact of climate change on growth of boreal, temperate and Mediterranean forests ecosystems: an overview. Int J Biometeorol. 2000; 44: 67-75.

16. McKenney DW, Pedlar JH, Lawrence K, Papadopol P, Campbell K, Hutchinson MF. Change and evolution in the plant hardiness zones of Canada. BioScience. 2014; 64(4): 341-50.

17. Menzel A, Sparks T, Estrella N, Roy DB. Altered geographic and temporal variability in phenology in response to climate change. Glob Ecol Biogeogr. 2006a; 15: 498-504.

18. Menzel E, Sparks TH, Estrella N, Koch E, Aasa A, Ahas R, Alm-Kübler K, Bissolli P, Braslavská O, Briede A, Chmielewski FM, Crepinsek Z, Curnel Y, Dahl Å, Defila C, Donnelly A, Filella Y, Jatczak K, Måge F, Mestre A, Nordli $\varnothing$, Peñuelas J, Pirinen P, Remišová V, Scheifinger H, Striz M, Susnik A, Van Vliet AJH, Wiegolaski FE, Zach Z, Zust A. European phenological response to climate change matches the warming pattern. Glob Change Biol. 2006b; 12: 1-8.

19. Morin X, Roy J, Sonie L. Changes in leaf phenology of three European oak species in response to experimental climate change. New Phytol. 2010; 186(4): 900-10.

20. Nordli O, Wielgolaski FE, Bakken AK. Regional trends for bud burst and flowering of 
woody plants in Norway as related to climate change. Int. Jour. Biometeorol. 2008; 52(7): 625-39.

21. Parmesan C, Yohe G. A globally coherent fingerprint of climate change impacts across natural systems. Nature. 2003; 421(2): 37-42.

22. Polgar CA, Primack RB. Leaf-out phenology of temperate woody plants: from trees to ecosystems. New Phytol. 2011; 191: 926-41.

23. Primack RB, Higuchi H, Miller-Rushing AJ. The impact of climate change on cherry trees and other species in Japan. Biol. Conserv. 2009; 142(9): 1943-9.

24. Root TL, Price JT, Hall KR, Schneider SH, Rosenzweig C, Pounds JA. Fingerprints of global warming on wild animals and plants. Nature. 2003; 421(2): 57-60.
Asta Malakauskienė, Adomas Vitas

\section{KLIMATO ŠILTĖJIMO SĄLYGOTI INTRO- DUKUOTŲ SPYGLIUOČIŲ RŪŠIŲ PUM- PURŲ BRINKIMO FENOFAZĖS POKYČIAI ATSIŽVELGIANT İ JŲ NATŪRALIŲ AREALŲ ATŠIAURAUS KLIMATO ZONAS}

\section{Santrauka}

Besikeičiančios klimatinès sąlygos lemia medžių fenologijos pokyčius, kurie yra svarbūs rūšių išlikimui bei paplitimui vietinėse ekosistemose. Šio tyrimo tikslas - pagal ilgalaikių stebëjimų (1957-2016 m. arba 1980-2016 m.) duomenis ịvertinti 11 spygliuočių medžių rūšių, introdukuotų Lietuvoje, pumpurų brinkimo fenofazès atsaką ì klimato šiltèjimą atsižvelgiant ị jų natūralių arealų atšiauraus klimato zonas. Analizuotos 11 introdukuotų spygliuočių rūšių (Abies veitchii, Larix decidua, L. kaempferi, L. laricina, $L . \times$ marschlinsii, L. sibirica, L. sukaczewii, Picea mariana, Pinus mugo, Taxus baccata ir Thuja occidentalis) pumpurų brinkimo fenofazès pradžios datų sekos. Rezultatai rodo, kad 10-ies ị Lietuvą introdukuotų spygliuočių medžių rūšių pumpurų brinkimo fenofazė paankstèjo (pokyčių greitis svyravo nuo -0,10 iki -0,98 dienos / metus 19802016 m.), o Larix sukaczewii pumpurų brinkimo fenofazè vèlavo (atitinkamai +0,12 dienos / metus), ir tai daugiausia lèmė kovo mènesio temperatūra. Ryšys tarp stebètų spygliuočių medžių rūšių natūralių arealų atšiauraus klimato zonų ir pumpurų brinkimo fenofazès reakcijos ì klimato šiltejjimą buvo pastebètas tik lyginant vienos genties rūšis.

Raktažodžiai: pumpurų brinkimo fenofazè, klimato šiltėjimas, introdukuotų spygliuočių rūšys, atšiauraus klimato zonos 